\title{
The Development and Validation of the Distance Doctoral Program Integration Scale
}

\author{
Joe L. Holmes \\ Amanda Rockinson-Szapkiw \\ University of Memphis
}

\begin{abstract}
Research indicates academic integration and social integration are predictors of doctoral student persistence at any program stage. However, researchers have not defined, operationalized, and measured academic or social integration consistently. Further, no instruments exist that measure academic and social integration of doctoral students in distance programs. This research aimed to define distance doctoral program integration and develop and analyze the structure, validity, and reliability of the Distance Doctoral Program Integration Scale. Instrument development followed a multi-step process, including expert review, pilot test, and exploratory factor analysis. Instrument reliability was assessed using Cronbach's alpha and test-retest. The results indicated a three-factor structure (i.e., faculty integration, student integration, and curriculum integration). The 32-item instrument is valid and reliable, measuring program integration of doctoral students studying at a distance.
\end{abstract}

Keywords: academic integration, distance education, doctoral attrition, doctoral persistence, social integration

Holmes, J.L. \& Rockinson-Szapkiw, A. (2020). The development and validation of the distance doctoral program integration scale. Online Learning, 24(4), 182-203.

https://doi.org/10.24059/olj.v24i4.1951

\section{The Development and Validation of the Distance Doctoral Program Integration Scale}

Research over the past 40 years demonstrates that doctoral student persistence is low. In the traditional setting, only $40 \%$ to $60 \%$ of doctoral students persist (Bowen \& Rudenstine, 1992; Cassuto, 2013; Council of Graduate Schools, 2008; Ivankova \& Stick, 2007; Lovitts \& Nelson, 2000). In the distance education (DE) environment, doctoral students persist at rates $10 \%$ to $20 \%$ lower (Carr, 2000; Frankola, 2001; Terrell, 2005). According to Tinto (1993), doctoral student persistence is "shaped by the personal and intellectual interactions that occur within and between students and faculty and the various communities that make academic and social systems of the institution" (p. 231). Tinto's (1993) constructs of integration, specifically academic integration and 
social integration, capture the idea that both personal and institutional variables and the interaction of the two influence a doctoral student's choice to persist. The purpose of this study was to apply Tinto's constructs to doctoral education by defining, operationalizing, and developing an instrument to measure academic integration and social integration of doctoral students in Distance Education (DE)programs.

Academic integration refers to interaction among students and faculty within the formal academic domain, and social integration refers to interaction among students and faculty outside the formal academic domain (Tinto, 1993). Tinto's (1975, 1993) model and constructs of academic integration and social integration may be considered the most respected, tested, confirmed, and widely-cited work on integration and persistence (Kember, 1989, 1995; Simpson, 2003). Researchers have used Tinto's $(1975,1993)$ work on student integration as foundational in the development of models for doctoral student persistence (Wao \& Onwuegbuzie, 2011) and DE student persistence (Rovai, 2003).

Researchers suggest academic integration and social integration are two predictors of doctoral student persistence in DE programs (Berry, 2017; Ivankova \& Stick, 2007; RockinsonSzapkiw, L.S. Spaulding, \& M.T. Spaulding, 2016; Wyman, 2012). However, definitions and measurement of academic integration and social integration are not always consistent (Braxton, 2000; Braxton \& Lien, 2000; Davidson, Beck, \& Milligan, 2009; Davidson \& Wilson, 2013). Exacerbating inconsistencies are the variations of academic integration and social integration across program levels (e.g., doctoral, undergraduate, community college), and delivery methods (distance, commuter, residential) (Davidson \& Wilson, 2013).

Further, researchers have noted that academic integration and social integration may not be mutually exclusive constructs (Braxton \& Lien, 2000; Braxton, Sullivan, \& Johnson, 1997) for doctoral students. At the doctoral level, research suggests academic and social circles become the same (Lovitts, 2001; Tinto, 1993). In other words, doctoral students' academic and social interactions are often intertwined with many of the same students, faculty, and staff, making differentiation difficult (Lovitts, 2001; Tinto, 1993, 2017).

There are currently validated instruments that measure aspects of academic integration and social integration. For example, the College Persistence Questionnaire (CPQ) contains items that measure aspects of academic and social integration of traditional undergraduate college students (Davidson et al., 2009, Davidson, Beck, \& Grisaffe, 2015). The Classroom Community Scale (CCS) contains items closely aligned with academic and social integration but was designed specifically for single classes (Rovai, 2002a). The Doctoral Student Connectedness Scale (DSCS) (Terrell et al., 2009) also contains items that closely align with academic and social integration but was designed for students in their program's dissertation stage. None of these instruments was found suitable for fully measuring the identified elements of academic integration and doctoral students' social integration in DE programs.

This study's impetus was the lack of understanding of academic integration and social integration of doctoral students in DE programs. The following research questions guided this study:

(a) What are the underlying factors that explain the integration of distance doctoral students? (b) Is the instrument valid and reliable for measuring integration of distance doctoral students? 


\section{Review of Relevant Literature}

A thorough literature review indicated that doctoral students' integration in DE programs comprises elements of academic integration and social integration, thereby forming the foundation for instrument development. The literature suggested that doctoral students' academic integration in DE programs includes satisfaction levels with the academic program, student-faculty academic interactions, and student-student academic interactions. The literature suggested that doctoral students' social integration in DE programs includes satisfaction levels with the nature and quality of student-student and student-faculty nonacademic interactions within the doctoral program. We, therefore, used this literature as the basis for initial instrument development.

\section{The Importance of Integration for Doctoral Students in DE Programs}

The doctoral journey is marked with "challenges and demands of doctoral study" (Smith, Maroney, Nelson, Label, \& Abel, 2006, p.17). The doctoral journey is unique because development as an independent scholar is an essential, albeit one of the most difficult parts of the process (Gardner, 2008; Walker, Golde, Jones, Bueschel, \& Hutchings, 2008). Gardner (2008) described the paradox in doctoral education: "If someone holds your hand too much, you'll never learn to think for yourself, and if someone doesn't hold your hand enough you'll fall flat on your face" (p. 327). Success in the doctoral journey is rooted in developing as an independent scholar and in integration throughout the process.

Lovitts (2005) purported that three factors affect doctoral degree completion, including individual factors, the microenvironment (e.g., department, program, peers, and faculty), and the macroenvironment (e.g., the culture of education and discipline). The actions both faculty and students take to integrate doctoral students into the program, and department with peers and faculty are significant in the microenvironment. Golde (2005) agreed that integration leads to doctoral student persistence. In fact, integration-related reasons have been cited as the most common reason doctoral students continue (Lovitts, 2001).

During the doctoral journey, students integrate within and throughout their program. Students begin to develop academic and social circles during initial coursework. As they progress, interactions become much more localized and influenced by the faculty and student communities existing in their respective fields of study (Tinto, 1993). These interactions are often intertwined with many of the same students, faculty, and staff. During the dissertation, the sphere of integration shrinks significantly, generally to the few faculty involved in the dissertation process (Tinto, 1993). The ability to integrate and develop positive working relationships within the program at this stage is so critical to persistence "that it may hinge largely if not entirely upon the behavior of a specific faculty member" (Tinto, 1993, p. 237). Understanding the elements of academic integration and social integration of doctoral students in DE programs is vital for researchers, faculty members, and administrators, given that integration is predictive of persistence, and persistence is a problem.

\section{Academic Integration for Doctoral Students in DE Programs}

Though the definition and measurement of academic integration have varied even within doctoral studies, critical lines of doctoral education research for both distance and residential students have consistently described academic integration as important in understanding doctoral student persistence (Bair, 1999; Ivankova \& Stick, 2007; Lovitts, 2001; Rockinson-Szapkiw et al., 2016; Rovai, 2003; Spaulding \& Rockinson-Szapkiw, 2012; Tinto, 1993; Wao \& Onwuegbuzie, 
2011; Wyman, 2012). The level of academic integration has been linked to satisfaction, and the literature suggests higher satisfaction levels positively influence doctoral student persistence (Bair, 1999; Ivankova \& Stick, 2007) and time to degree (Wao \& Onwuegbuzie, 2011). For doctoral students, academic integration happens and is important in all phases of their program (e.g., coursework, comprehensive examinations, or dissertation) (Bair, 1999; Golde, 2000; RockinsonSzapkiw \& Spaulding, 2014; Tinto, 1993). Drawing from a thorough review of the literature, distance doctoral student academic integration was defined as the student's satisfaction with (a) the academic program, (b) student-faculty academic interactions, and (c) student-student academic interactions. Items were developed to encapsulate these elements.

\section{Academic program}

Doctoral student's satisfaction with the academic program has been identified as being positively associated with doctoral student persistence in both the traditional and distance environments (e.g., Bair, 1999; Girves \& Wemmerus, 1988; Ivankova \& Stick, 2007; Lindsay, Kerawalla, \& Floyd, 2018; Lovitts, 2001; Rockinson-Szapkiw et al., 2016; Rovai, 2002b; Wao \& Onwuegbuzie, 2011). Indicators of academic program satisfaction in both the traditional and distance environments are very similar. For example, in her meta-synthesis of nearly 30-years of residential doctoral student persistence and attrition research, Bair (1999) identified the academic program satisfaction aspects most closely related to persistence as perceived academic quality and relevancy of the curriculum and instruction to the student's work. Research has since supported Bair's (1999) findings.

In their mixed methods study of factors related to residential doctoral student time-todegree, Wao and Onwuegbuzie (2011) found that students who were satisfied with their courses, the sequencing of courses, and with the level of coursework prepared them for the dissertation tended to have shorter completion times (Wao \& Onwuegbuzie, 2011). Likewise, persistence increased, and time-to-degree decreased when residential students were interested in their coursework and dissertation topic (e.g., there is good fit with personal interests, application to future job goals, application to real life, or other similar reasons) (Bair, 1999; Earl-Novell, 2006; Golde, 2005; Hoskins \& Goldberg, 2005; Lindsay et al., 2018; Spaulding \& Rockinson-Szapkiw, 2012; Wao \& Onwuegbuzie, 2011). Research indicates similar findings in the distance environment. Doctoral students in DE programs who perceived higher levels of learning, course relevance, and course usefulness indicated greater academic program satisfaction or academic integration (Ivankova \& Stick, 2007; Rovai, 2002b).

\section{Student-faculty academic interactions}

In a meta-synthesis, Bair (1999) also identified "the single most frequently-occurring finding...was that successful degree completion is related to the degree and quality of contact between a doctoral student and her or his advisor(s) or other faculty in the student's doctoral program" (pp. 67-68). Positive academic-focused relationships with faculty can decrease time-todegree (Maher, Ford, \& Thompson, 2004; Wao \& Onwuegbuzie, 2011). This need for positive student-faculty interactions coincides with Moore's (1989) suggestion that positive academicbased faculty interaction is essential and desirable in the DE setting.

Faculty interactions in DE programs can be either synchronous or asynchronous and take place using a variety of methods, including telephone, live video, online chat, email, discussion board, and SharePoint sites (Grable, 2011; Moore, 2019; Simonson, Smaldino, Albright, \& Zvacek, 2012; Terrell et al., 2012). Operant terms used to describe positive aspects of academic- 
based faculty interactions in both the traditional and distance environments include accessible, helpful, committed, timely, and quality feedback (e.g., Bair, 1999; Golde, 2005; Ivankova \& Stick, 2007; Maher et al., 2004; Wao \& Onwuegbuzie, 2011). Examples of negative academic-based faculty interactions include terms such as lack of cooperation, dictatorial, controversial, challenging or difficult, lack of direction, unhelpful, and unavailable (e.g., Bair, 1999; Golde, 2005; Lovitts, 2001; Spaulding \& Rockinson-Szapkiw, 2012; Willis \& Carmichael, 2011). The terms rupture and derailment were used by Golde (2000) to highlight how dramatic difficult interactions between doctoral students and faculty can be.

\section{Student-student academic interactions}

Similar to the need for positive academic-based student-faculty interactions, Moore (1989) suggested positive, academic-based student-student (or peer) interaction is very important in the distance environment. Academic-based peer interactions are those related to program completion (e.g., coursework, comprehensive examinations, or dissertation) (Bair, 1999; Lovitts, 2001; Rovai, 2014; Wao \& Onwuegbuzie, 2011). These academic interactions can be formal or informal (whether online or in the classroom) and can occur on a regular or irregular basis (Lovitts, 2001).

Academic interactions among peers occur using similar means as those previously described for student-faculty interactions (Moore, 1993, 2019; Simonson et al., 2012). However, the frequency of interaction does not necessarily correlate to higher satisfaction levels with interaction. In DE, interaction quality is more important than quantity (Picciano, 2002; Rovai, 2014; Simonson et al., 2012), and students with low interaction frequencies may still be satisfied with their interaction levels (Picciano, 2002).

Operant terms used to describe positive aspects of academic-based peer interactions in both the traditional and distance environments include willing, helpful, opportunity to learn from others, share knowledge and examples, and constructive peer feedback (e.g., Ivankova \& Stick, 2007; Lovitts, 2001; Maher et al., 2004; Simonson et al., 2012; Spaulding \& Rockinson-Szapkiw, 2012; Terrell, 2012). Examples of negative aspects of academic-based peer interactions include terms such as lack of cooperation, argumentative, singlemindedness, little interaction, lack of interest, one-way communications, oblivious to others, different learning goals, competitive, and unwilling (e.g., Golde, 2005; Lovitts, 2001; Rovai, 2014).

\section{Social Integration for Doctoral Students in DE Programs}

Similar to academic integration, researchers have provided empirical support that social integration is a predictor of doctoral student persistence in both the traditional and DE settings (e.g., Bair, 1999; Golde, 2005; Ivankova \& Stick, 2007; Lovitts, 2001; Rockinson-Szapkiw et al., 2016; Spaulding \& Rockinson-Szapkiw, 2012; Terrell et al., 2009; Terrell et al., 2012; Tinto, 1993; Wao \& Onwuegbuzie, 2011; Wyman, 2012). Like academic integration, researchers have operationalized and measured social integration in various ways with no widely accepted definition or measurement (Davidson et al., 2009; Davidson \& Wilson, 2013). These inconsistencies contribute to the difficulties described earlier in standardizing results regarding social integration effects on persistence (Braxton, 2000; Braxton \& Lien, 2000; Davidson et al., 2009; Davidson \& Wilson, 2013).

Exacerbating the issue is that doctoral students' social integration is closely intertwined and even blurred with academic integration (Lovitts, 2001; Tinto, 1993). Researchers have referenced academic-related factors (e.g., timeliness of faculty feedback, course-related conversations outside 
the classroom, and interactions within the doctoral department) when describing the social integration of doctoral students (Bair, 1999; Golde, 2000; Terrell et al., 2009; Wao \& Onwuegbuzie, 2011). However, researchers do agree that for doctoral students, social integration is a consequence of academic and nonacademic interactions (Bair, 1999; Golde, 2005; Ivankova \& Stick, 2007; Lovitts, 2001; Rockinson-Szapkiw et al., 2016; Spaulding \& Rockinson-Szapkiw, 2012; Terrell et al., 2009; Terrell et al., 2012; Tinto, 1993; Wao \& Onwuegbuzie, 2011; Wyman, 2012). Drawing from a thorough review of the literature, distance doctoral student social integration was defined as the student's satisfaction with the nature and quality of student-student and student-faculty nonacademic interactions within the program. Items were developed to encapsulate these elements.

Social integration of doctoral students is developed "through informal, casual interactions between and among graduate students and graduate faculty in a variety of contexts" (Lovitts, 2001, p. 42). These interactions, in DE programs, can stem from any peer and faculty interactions (Rockinson-Szapkiw et al., 2016; Rovai, 2002a; Terrell et al., 2009; Terrell et al., 2012). Hill (1996) posited it is important to understand the contexts of interactions. Positive feelings of interactions "may not be defined in a geographical sense [and may] consist of groupings of people who...may never physically meet each other" (Hill, 1996, p. 433) such as the DE environment.

Peer and faculty interactions help develop positive relationships and feelings of being connected to others in the distance environment (Garrison, Anderson, \& Archer, 2000; Ivankova \& Stick, 2007; Moore, 2019; Rockinson-Szapkiw et al., 2016; Terrell et al., 2009; Terrell et al., 2012). The literature suggests when interactions are positive, students are connected or integrated with fellow students and faculty within the program (Lovitts, 2001; Rockinson-Szapkiw et al., 2016; Terrell et al., 2009; Rovai, 2002a, 2002b, 2014; Tinto, 1993). Ivankova and Stick (2007) purported that doctoral students in DE programs who feel supported by and perceive encouragement from peers and faculty within a bounded system of a course or participation in online activities (academic or nonacademic) indicates good social integration.

Drawing from the literature, indicators of a doctoral student being satisfied with the level of social integration include operant terms such as feelings of closeness, cohesion, trust, spirit, personal relationships, and safety and feelings that peers and faculty are approachable, cooperative, supportive, caring, and encouraging (Bair, 1999; Bowen \& Rudenstine, 1992; Girves \& Wemmerus, 1988; Ivankova \& Stick, 2007; Lovitts, 2001; Rovai, 2002a; Terrell et al., 2009; Wao \& Onwuegbuzie, 2011; Wyman, 2012). These feelings indicate a sense of acceptance, belonging, and trust, suggesting higher satisfaction levels of social integration (RockinsonSzapkiw et al., 2016; Terrell et al., 2009; Terrell et al., 2012). Positive peer and faculty interactions and the feelings associated with those interactions' nature can have a positive influence on the volition to persist (Rovai, 2014; Wao \& Onwuegbuzie, 2011).

Indicators of poor social integration of doctoral students include operant terms such as a lack of understanding, not encouraging, feelings of competitiveness and competition, neglect, and personal issues with dissertation committees and chair advisor (Bair, 1999; Bowen \& Rudenstine, 1992; Girves \& Wemmerus, 1988; Ivankova \& Stick, 2007; Lovitts, 2001; Rovai, 2002a; Terrell et al., 2009; Wao \& Onwuegbuzie, 2011; Wyman, 2012). Lovitts (2001) found terms related to feelings of isolation (e.g., lack of cohesion, social deprivation, isolated, and little personal contact) as "the most frequently cited integration-related reasons" (p. 177) leading to doctoral student decisions to exit a program. Lovitts $(2001,2005)$ also noted that feelings of isolation and disconnectedness from faculty and their peers, especially during the dissertation phase, were 
indicators that social integration was not present. Terrell et al. (2009) suggested that doctoral students in DE programs who do not interact face-to-face with peers and faculty on campus may experience feelings of isolation and disconnectedness at an exacerbated level.

\section{Methods}

\section{Participants}

Participants for this study consisted of a snowball sample of 282 DE students enrolled in educational doctorate programs in late 2018 across multiple higher education institutions. Snowball sampling included emails sent to industry professionals with access to potential participants and posting an invitation to participate in professional organization listservs (e.g., AERA,VACES). The researchers used snowball sampling to access participants from multiple institutions as a means to increase participant demographic variability and increase generalizability (Warner, 2013). The researchers limited participants to those enrolled in only educational doctorate programs (either $\mathrm{EdD}$ or $\mathrm{PhD}$ ) as a means to minimize the effects of variability across multiple doctoral program disciplines (Gall, Gall, \& Borg, 2007).

This study focused on distance education programs considered online as at least $80 \%$ of the program was delivered online (Allen \& Seaman, 2014). This definition of distance education is consistent with the Integrated Postsecondary Education Data System's (IPED) two categories of distance education enrollment used in Seaman, Allen and Seaman's (2018) distance education report. The term distance education included exclusively distance education $(100 \%$ enrollment in online courses) and some but not all distance education (e.g., enrollment in courses including mixed modalities with some online courses).

Participants were pursuing PhDs $(n=49,13.8 \%)$ and EdDs $(n=243,86.2 \%)$ in areas such as Curriculum and Instruction $(n=101,35.8 \%)$, Educational Leadership $(n=123,43.7 \%)$, Higher or Adult Education $(n=20,7.1 \%)$, and Instructional Design and Technology $(n=13,4.6 \%)$. The majority of the participants reported that they were actively working on their dissertations $(n=$ $145,50.3 \%)$, while others were in year one $(n=57,19.8 \%)$ or year two $(n=85,29.5 \%)$ of their doctoral journeys. Males represented $27.7 \%(n=78)$ of participants, and $72.3 \%(n=204)$ of the participants identified as females. The participants were primarily Caucasian $(n=208,73.8 \%)$, ranging from age 20 to over 80 .

\section{Instrumentation and procedures}

A literature review suggested that integration, regardless of setting or program level, is inclusive of both academic and social integration. However, research demonstrating the links between persistence, academic integration, and social integration are sometimes not clear (e.g., Braxton \& Lien, 2000; Braxton et al., 1997), and these two constructs at the doctoral level are closely intertwined (Lovitts, 2001; Tinto, 1993). Thus, drawing from the literature on social and academic integration of doctoral students in DE programs, including previously developed instruments such as the CPQ (Davidson et al., 2009; Davidson et al., 2015), the CCS (Rovai, 2002a), and the DSCS (Terrell et al., 2009), 50 items were developed for the instrument.

All items were positively worded and asked respondents to rate their level of satisfaction with the potential responses of very high (5), high (4), medium (3), low (2), or very low (1). The scores for each identified subscale were computed by adding the item points and averaging them. Higher scores reflect stronger integration. The initial instrument items were assessed for content 
and face validity by a subject matter expert (SME) panel (Warner, 2013). The SME panel was comprised of four experts who had published on doctoral persistence, online persistence, or online education. All had experience teaching within online doctoral programs. The SME panel review consisted of two reviews.

During the first review, the SME panel examined the instrument items for the following criteria: content validity, face validity, clarity, conciseness, and reading level (Worthington \& Whittaker, 2006). The experts rated each item for each criterion using a five-point scale (one $=$ very poor; five $=$ very good). The experts also provided open responses explaining ratings of items and providing suggested improvements. Mean scores for each item were computed and comments were analyzed. Any item that did not have a score of 4 out of 5 was adjusted or deleted. Suggestions were used to modify items. The items were then again provided to the reviewers. During the second review, the SME panel selected the instrument items in aggregate that appeared to fully measure distance doctoral student integration. The panelists reached a consensus that 34 of the items appeared to fully measure distance doctoral student integration.

The 34-item scale was then assessed in a pilot study. The pilot study was conducted with sample participants $(n=8)$ to assess the scale for face validity, item relevancy, and obtain an estimated time-to-complete (Warner, 2013). Feedback and evaluation from the pilot participants indicated the 34-item scale was ready for further evaluation.

Snowball sampling (Gall et al., 2007) was used to get participants for the next step. Following Dillman, Smyth, and Christian's (2009) recommendation, an invitation email to participate in the study was sent to students and faculty associated with distance doctoral education programs at nine institutions. Additionally, an invitation to complete an online survey consisting of demographic questions, program experience questions, and the 34-item scale was sent to doctoral students via professional organization listservs. Within the email invitation, the participation criteria was defined as enrollment in an education doctorate program in which $80 \%$ or more of the course work was completed online. Initially 322 students responded to the survey.

A small amount of the cases $(n=34)$ were deleted due to missing a large amount of data. An additional five cases were disqualified as the respondents indicated they were not in a distance doctoral program. There were also 15 cases with what appeared to be data missing completely at random that we chose to retain by imputing the missing data using mean substitution (Tabachnick $\&$ Fidell, 2007). The final sample consisted of 282 cases with valid and complete responses. This sample size was well within the acceptable limits for the exploratory factor analysis (EFA) (Comrey \& Lee, 1992; Kass \& Tinsley, 1979; Warner, 2013).

\section{Results}

Data were assessed and found suitable for analysis. Inspection of the correlation matrix indicated many of the coefficients were greater than the threshold of .3 (Tabachnick \& Fidell, 2007). The Kaiser-Meyer-Olkin Measure of Sampling Adequacy was 0.961 and exceeded the needed .6 critical value (Kaiser, 1974). The Bartlett's Test of Sphericity was statistically significant $\left(p<.001 ; \chi^{2}=8001.279\right)$, supporting the factorability of the correlation matrix and assumption of multivariate normality (Tabachnick \& Fidell, 2007). Thus, to investigate the instrument's validity and structure, a maximum likelihood method of EFA with oblique rotation was conducted. Maximum likelihood is the preferred method when data are suitable and are 
generally normally distributed (Fabrigar, Wegener, MacCallum, \& Strahan, 1999). The decision to retain a three-factor solution was made based on analysis of the eigenvalues inspection, Cattell's (1966) scree plot inspection, parallel analysis, interpretability criteria, and consideration of conceptual understanding of the literature. The correlation matrix (see Table 1) contained numerous underlying correlations greater than .3, supporting the use of oblique rotation (Fabrigar et al., 1999; Tabachnick \& Fidell, 2007).

All but 2 of the 34 items (items 9 and 30) loaded on one of the three factors. Many items loaded strongly on a primary factor (i.e., above a .5; Tabachnick \& Fidell, 2013). Two items (items 1 and 4) had communalities $\left(h_{2}\right)$ with values below .4 (see Table 2). However, the matrix (see Table 2) indicated all items were above the higher cutoff threshold of .5 (Kahn, 2006). Therefore, the decision was made to retain 32 items (items 9 and 30 were removed). The factors were named: (a) faculty integration, (b) student integration, and (c) curriculum integration. Mean scores for each factor are also in Table 2.

The internal consistency of the 32-item instrument was assessed using Cronbach's alpha coefficient. The Cronbach's alpha coefficient for the instrument was .966, indicating excellent reliability (George \& Mallery, 2003). The Cronbach's alpha coefficient for the faculty integration factor and student integration factor was .937 and .957 respectively. Both factors indicated excellent reliability. The Cronbach's alpha coefficient for the curriculum factor was .899 indicating good reliability. Test-retest reliability was also calculated approximately four weeks after the initial round of participation using data from 109 participants (Warner, 2013). The Pearson correlation for the instrument was $r(107)=.855, p<.01$. The faculty integration factor was $r(107)=.780, p<.01$, the student integration factor was $r(107)=.810, p<.01$, and the curriculum factor was $r(107)=.842, p<.01$. These results were above the reliability measurement criteria of .70 suggested by Warner (2013), providing further evidence that the instrument is reliable.

\section{Discussion}

This study examined the dimensionality, validity, and reliability of an instrument created to measure distance doctoral students' integration. In this study, the instrument was developed, refined, and tested with 282 students enrolled in doctoral programs in education that were offered online. Evidence from the exploratory factor analysis and internal consistency analysis demonstrated that the 32-item self-report instrument has both validity and reliability. The final scale was found to have three dimensions. These results surprised the researchers.

The researchers designed the instrument to measure elements of academic integration (satisfaction with the academic program, student-faculty academic interactions, and studentstudent academic interactions) and social integration (satisfaction with the nature and quality of student-faculty nonacademic interactions and student-student nonacademic interactions). The curriculum related items loaded as expected. However, the rest of the items loaded differently than expected. Using interpretability criteria (O'Rourke \& Hatcher, 2013), it was clear all facultyrelated items loaded on one factor, all student-related items loaded on a second factor, and all curriculum items loaded on a third scale. These loadings indicated the importance was who the interaction was with, not the type of interaction. 
The identified dimensions appear to more accurately describe the integration of distance doctoral students than academic integration and social integration, as described in the literature. The literature described that, at the doctoral level, academic integration and social integration become intertwined (Lovitts, 2001; Tinto, 1993). However, the results of this study indicate the term intertwined may not go far enough. Perhaps a better term is conjoined.

Merriam-Webster's (2018) thesaurus recommends the use of conjoining to describe how separate items "come together as a single unit" (para 1). In this research, items designed to separately measure academic integration and social integration conjoined by who the interaction was with (faculty or peers), not the interaction type (academic or social). These findings suggest the terms academic integration and social integration as used in the literature, do not adequately explain the integration of doctoral students studying at a distance.

Therefore, in lieu of the separate terms academic integration and social integration, we suggest the term program integration be used, and offer the following as a more accurate definition of program integration for doctoral students in distance programs: the satisfaction level with faculty integration, student integration, and curriculum integration. We also suggest the following definitions for the three identified dimensions. Faculty integration is the satisfaction level with the nature and quality of academic and nonacademic student-faculty interactions that take place during the distance doctoral program. Student integration is the satisfaction level with the nature and quality of academic and nonacademic student-student interactions that take place during the distance doctoral program. Curriculum integration is the satisfaction level with the quality and relevancy of the curriculum in the distance doctoral program. We also aptly named the instrument the Distance Doctoral Program Integration Scale (DDPIS).

\section{Implications}

This research may help narrow the gap in understanding program integration of doctoral students in DE programs. The literature is clear there is a link between integration and the persistence of doctoral students in DE programs (Bair, 1999; Golde, 2005; Ivankova \& Stick, 2007; Lovitts, 2001; Rockinson-Szapkiw et al., 2016; Spaulding \& Rockinson-Szapkiw, 2012; Rovai, 2003; Terrell et al., 2009; Terrell et al., 2012; Tinto, 1975, 1993; Wao \& Onwuegbuzie, 2011; Wyman, 2012). This instrument may be used to further understand the importance of program integration and may also help decision makers identify and mitigate program integration issues at any stage in the doctoral student's journey, thereby increasing persistence.

\section{Limitations}

This study is empirically significant and has practical value; however, the study is not without limitations. It is understood that EFA is an exploratory method. While multiple methods of factor extraction and interpretability criteria (O’Rourke \& Hatcher, 2013) were used to identify the best factor solution, "decisions about number of factors and rotational scheme are based on pragmatic ... criteria" (Tabachnick \& Fidell, 2007, p. 611). Although it is not likely given the multiple high variable loadings that were statistically significant, a thorough review of the literature to inform item development, and the use of a SME review, false correlations could still be a limitation of this study (Tabachnick \& Fidell, 2007). The sample size also brought a potential limitation. For factor analysis, many (Comrey \& Lee, 1992; Kahn, 2006; Warner, 2013) recommend a sample size of at least 300. The $n$ of 282 could be considered a small sample size and reduced reliability of correlation coefficients. This study also used a convenience sample delimited to a specific population (e.g., doctoral students in an 
asynchronous online school of education program with $80 \%$ of the program delivered at a distance). Narrowing the sample to a specific population is a delimiter that reduced the ability to generalize results (Warner, 2013) to a larger population of doctoral students across various disciplines (e.g., technology, engineering, and math [STEM] degrees). These limitations provide impetus for future research.

\section{Recommendations for Future Research}

The results of this study indicate the DDPIS is a valid and reliable instrument for measuring distance doctoral student program integration. Given the exploratory nature of this study, there is certainly the need to continue research on the DDPIS and doctoral program integration. Recommendations for future research include the following:

- Conduct a confirmatory factor analysis (CFA) on the DDPIS to confirm the factor structure.

- Conduct research to increase generalizability. The eventual goal is for the DDPIS to be a valid and reliable instrument for doctoral students in additional non-STEM and STEM DE programs.

- Conduct a longitudinal study to determine if the DDPIS is able to predict persistence and time-to-degree of doctoral students in DE programs.

- Conduct prediction studies to determine integration differences of doctoral students in various program stages.

- Conduct studies using the DDPIS in targeted populations to see how demographic variables may be associated with integration and persistence.

\section{Conclusions}

Many personal, microenvironment, and macroenvironment factors influence a doctoral student's persistence (Lovitts, 2005) and research clearly suggests two of the primary predictors of doctoral student persistence in DE programs are academic integration and social integration (Ivankova \& Stick, 2007; Rockinson-Szapkiw et al., 2016; Wyman, 2012). However, there was no widely accepted definitions or instruments that clearly define, operationalize, and measure distance doctoral student program integration. Confounding the issue was research demonstrating the links between persistence, academic integration, and social integration are sometimes not clear (e.g., Braxton \& Lien, 2000; Braxton et al., 1997). The literature describes that academic integration and social integration of doctoral students are closely intertwined (Lovitts, 2001; Tinto, 1993), yet the literature reviewed (e.g., Bair, 1999; Girves \& Wemmerus, 1988; Golde, 2005; Ivankova \& Stick, 2007; Lovitts, 2001; Lovitts \& Nelson, 2000; Rockinson-Szapkiw et al., 2016; Rovai, 2002a, 2003, 2014; Terrell et al., 2009; Terrell et al., 2012; Tinto, 1993; Wao \& Onwuegbuzie, 2011) described academic integration and social integration of doctoral students as separate constructs. In fact, Lovitts (2001) posited that while academic integration is necessary for completion, social integration is not.

This research provided strong evidence that academic integration and social integration may actually be conjoined. It was evident through this research that distance doctoral program integration is important to doctoral students but is inclusive of the factors of faculty, student, and 
curriculum integration. For distance doctoral students, in addition to satisfaction with the curriculum, the level of satisfaction with their interactions with both faculty and peers - regardless of whether academic or social — is what appears important at all stages of the doctoral journey.

The DDPIS was developed to measure integration of distance doctoral students at any stage of their program. As students navigate a doctoral program, their needs and abilities to integrate may change (Tinto, 1993). For example, in the early stage of their program, students attempt to find their place as they try to integrate into their program's communities (Tinto, 1993). Later in the program, integration tends to become more localized within smaller communities and eventually narrows to the few (e.g., student cohort, committee, and chair) involved in the dissertation process (Tinto, 1993). Therefore, the DDPIS may be used as a formative assessment at any stage to provide information about integration and address integration-related issues that may lead to attrition.

Universities have a responsibility to identify factors that promote doctoral student persistence (Bair, 1999), and the DDPIS has substantial utility for faculty and administrators of distance doctoral programs to identify program integration issues or at-risk students. Armed with the ability to identify integration shortfalls associated with program persistence, universities can develop and implement policies and targeted initiatives that promote doctoral student program integration. Research indicates students who are satisfied with their integration are more likely to persist. 


\section{References}

Allen, I. E., \& Seaman, J. (2014). Changing grade: Tracking online education in the United States. Online Learning Consortium. Retrieved from http://sloanconsortium.org/publications/survey/grade-change-2013

Bair, C. R. (1999). Doctoral student attrition and persistence: A meta-synthesis. (Doctoral dissertation, Loyola University Chicago). Available from ProQuest Dissertations and Theses database. (Order No. 9917754)

Berry, S. (2017). Student support networks in online doctoral programs: Exploring nested communities. International Journal of Doctoral Studies, 12, 33-48

Bowen, W. G., \& Rudenstine, N. L. (1992). In pursuit of the PhD. Princeton University Press.

Braxton, J. M. (2000). Reworking the student departure puzzle. Vanderbilt University Press.

Braxton, J. M., \& Lien, L. A. (2000). The viability of academic integration as a central construct in Tinto's interactionalist theory of college student departure. In J. M. Braxton (Ed.), Reworking the student departure puzzle (pp. 9-18). Vanderbilt University Press.

Braxton, J. M., Sullivan, A. S., \& Johnson, R. (1997). Appraising Tinto's theory of college student departure. In J. Smart (Ed.), Higher education: Handbook of theory and research, Vol. 12 (pp. 107-164). Agathon.

Carr, S. (2000). As distance education comes of age, the challenge is keeping the students. The Chronicle of Higher Education, 46(23), A39-A41.

Cassuto, L. (2013). Ph.D. attrition: How much is too much? The Chronicle of Higher Education. Retrieved from http://chronicle.com/article/PhD-Attrition-How-Much-Is/140045/

Cattell, R. B. (1966). The scree test for the number of factors. Multivariate Behavioral Research, 1, 245-276.

Comrey, A. L., \& Lee, H. B. (1992). A first course in factor analysis (2nd ed.). Lawrence Erlbaum Associates.

Council of Graduate Schools. (2008). Ph.D. completion project: Program completion and attrition data. Retrieved from https://cgsnet.org/phd-completion-project

Davidson, W. B., Beck, H. P., \& Grisaffe, D. B. (2015). Increasing the institutional commitment of college students: Enhanced measurement and test of a nomological model. Manuscript submitted for publication.

Davidson, W. B., Beck, H. P., \& Milligan, M. (2009). The college persistence questionnaire: Development and validation of an instrument that predicts student attrition. Journal of College Student Development, 50(4), 373-390.

Davidson, C., \& Wilson, K. (2013). Reassessing Tinto's concepts of social and academic integration in student retention. Journal of College Student Retention: Research, Theory \& Practice, 15(3), 329-346. doi:10.2190/CS.15.3.b

Dillman, D. A., Smyth, J. J., \& Christian, L. M. (2009). Internet, mail, and mixed-mode surveys: The tailored design method (3rd ed.). Wiley \& Sons.

Earl-Novell, S. (2006). Determining the extent to which program structure features and integration mechanisms facilitate or impede doctoral student persistence in mathematics. International Journal of Doctoral Studies, 1, 45-57. 
Fabrigar, L. R., Wegener, D. T., MacCallum, R. C., \& Strahan, E. J. (1999). Evaluating the use of exploratory factor analysis in psychological research. Psychological Methods, 4(3), 272-299.

Frankola, K. (2001). Why online learners drop out. Workforce, 80(10), 52-60.

Gall, J.P., Gall, M.D., \& Borg, W.R. (2007). Educational research: An introduction (8th ed.). Pearson Education, Inc.

Gardner, S. (2008). "What's too much and what's too little?": The process of becoming an independent researcher in doctoral education. Journal of Higher Education, 79(3), 326-350.

Garrison, R. D., Anderson, T., \& Archer, W. (2000). Critical inquiry in a text-based environment: Computer conferencing in higher education, The Internet and Higher Education, 2(2-3) 87105. doi:10.1016/S1096-7516(00)00016-6

George, D., \& Mallery. (2003). SPSS for Windows step by step: A simple guide and reference (4th ed.). Allyn and Bacon.

Girves, J. E., \& Wemmerus, V. (1988). Developing models of graduate student degree progress. The Journal of Higher Education, 59(2), 163-189. doi:10.2307/1981691

Golde, C. M. (2000). Should I stay or should I go? Student descriptions of the doctoral attrition process. The Review of Higher Education, 23(2), 199-227.

Golde, C. M. (2005). The role of the department and discipline in doctoral student attrition: Lessons from four departments. The Journal of Higher Education, 76(6), 669-700.

Grable, J. E. (2011). Innovation in doctoral degrees designed for adult learners: A hybrid model in personal financial planning. In J. P. Pappas \& J. Jerman (Eds.), Meeting adult learner needs through the nontraditional doctoral degree (pp. 43-51). Jossey-Bass.

Hill, J. L. (1996). Psychological sense of community: Suggestions for future research. Journal of Community Psychology, 24(4), 431-438.

Hoskins, C. M., \& Goldberg, A. D. (2005). Doctoral student persistence in counselor education programs: Student-program match. Counselor Education and Supervision, 44(3), 175-188.

Ivankova, N. V., \& Stick, S. L. (2007). Students' persistence in a distributed doctoral program in educational leadership in higher education: A mixed methods study. Research in Higher Education, 48(1), 93-135. doi:10.1007/s11162-006-9025-4

Kahn, J. H. (2006). Factor analysis in counseling psychology research, training, and practice: Principles, advances, and applications. The Counseling Psychologist, 34(5), 684-718. doi:10.1177/0011000006286347

Kaiser, H. F. (1974). An index of factorial simplicity. Psychometrika, 39(1), 31-36.

Kass, R. A., \& Tinsley, H. E. A. (1979). Factor analysis. Journal of Leisure Research, 11(2), 120 138.

Kember, D. (1989). A longitudinal-process model of drop-out from distance education. The Journal of Higher Education, 60(3), 278-301.

Lindsay, H., Kerawalla, L., \& Floyd, A. (2018) Supporting researching professionals: EdD students' perceptions of their development needs. Studies in Higher Education, 43(12), 2321-2335.

Lovitts, B. E., \& Nelson, C. (2000). The hidden crisis in graduate education: Attrition from Ph.D. programs. Academe, 86(6), 44-50. doi:10.2307/40251951 
Lovitts, B. E. (2001). Leaving the ivory tower: The causes and consequences of departure from doctoral study. Rowan \& Littlefield Publishers, Inc.

Lovitts, B. E. (2005). Being a good course-taker is not enough: A theoretical perspective on the transition to independent research. Studies in Higher Education, 30(2), 137-154.

Maher, M. A., Ford, M. E., \& Thompson, C. M. (2004). Degree progress of women doctoral students: Factors that constrain, facilitate, and differentiate. Review of Higher Education, 27(3), 385-408.

Merriam Webster. (n.d.). Conjoined. In Merriam Webster's online thesaurus. Retrieved February 19, 2020, from https://www.merriam-webster.com/thesaurus/conjoined

Moore, M. G. (1989). Editorial: Three types of interaction. The American Journal of Distance Education, 3(2), 1-7. doi:10.1080/08923648909526659

Moore, M. G. (1993). Theory of transactional distance. In D. Keegan, (Ed.), Theoretical principles of distance education. Routledge.

Moore, M. G. (Ed.) (2019). Handbook of distance education (4th ed.). Lawrence Erlbaum Associates.

Picciano, A. G. (2002). Beyond student perceptions: Issues of interaction, presence, and performance in an online course. Journal of Asynchronous Learning Networks, 6(1), 21-40.

Rockinson-Szapkiw, A. J., \& Spaulding, L. S. (2014). Navigating the doctoral journey: A handbook of strategies for success. Rowman \& Littlefield.

Rockinson-Szapkiw, A. J., Spaulding, L. S., \& Spaulding, M. T. (2016) Identifying significant integration and institutional factors that predict online doctoral persistence. The Internet and Higher Education, 31, 101-112.

Rovai, A. P. (2002a). Development of an instrument to measure classroom community. The Internet and Higher Education, 5(3), 197-211.

Rovai, A. P. (2002b). Sense of community, perceived cognitive learning, and persistence in asynchronous learning networks. The Internet and Higher Education, 5(4), 319-332. doi: 10.1016/S1096-7516(02)00130-6

Rovai, A. P. (2003). In search of higher persistence rates in distance education online programs. The Internet and Higher Education, 6(1), 1-16. doi:10.1016/S1096-7516(02)00158-6

Rovai, A. P. (2014). Creating a scholarly community and collegial support system. In A. J. Rockinson-Szapkiw \& L. S. Spaulding (Eds.), Navigating the doctoral journey: A handbook of strategies for success (pp. 9-18). Rowman \& Littlefield.

Seaman, J. E., Allen, I., \& Seaman, J. (2018). Grade increase: Tracking online education in the United States. Babson Survey Research Group and Quahog Research Group. Retrieved from https://onlinelearningsurvey.com/reports/gradeincrease.pdf

Simonson, M., Smaldino, S., Albright, M., \& Zvacek, S. (2012). Teaching and learning at a distance: Foundations of distance education (5th ed.). Pearson Education, Inc.

Simpson, O. (2003). Student retention in online, open, and distance learning (Adobe Digital Editions version). Routledge. 
Smith, R., Maroney, K., Nelson, K., Label, A., \& Abel, H. (2006). Doctoral programs: Changing high rates of attrition. Journal of Humanistic Counseling, Education and Development, 45(1), $17-31$.

Spaulding, L. S., \& Rockinson-Szapkiw, A. J. (2012). Hearing their voices: Factors doctoral candidates attribute to their persistence. International Journal of Doctoral Studies, 7, 199 219.

Tabachnick, B. G., \& Fidell, L. S. (2007). Using multivariate statistics (5th ed.). Pearson Education Inc.

Terrell, S. (2005). Supporting different learning styles in an online learning environment: Does it really matter in the long run? Online Journal of Distance Education Administration, 8(2). Retrieved from http://www.westga.edu/ distance/ojdla/summer82/terrell82.htm

Terrell, S. R., Snyder, M. M., \& Dringus, L. P. (2009). The development, validation, and application of the Doctoral Student Connectedness Scale. The Internet and Higher Education, 12(2), 112-116. doi:10.1016/j.iheduc.2009.06.004

Terrell, S. R., Snyder, M. M., Dringus, L. P., \& Maddrey, E. (2012). A grounded theory of connectivity and persistence in a limited residency doctoral program. The Qualitative Report, 17(31), 1-14. Retrieved from http://www.nova.edu/ssss/QR/QR17/terrell.pdf

Tinto, V. (1975). Dropout from higher education: A theoretical synthesis of recent research. Review of Educational Research, 45(1), 89-125.

Tinto, V. (1993). Leaving college: Rethinking the causes and cures of student attrition (2nd ed.). The University of Chicago Press.

Tinto, V. (2017). Through the eyes of students. Journal of College Student Retention: Research, Theory \& Practice, 19(3), 254-269.

Walker, G., Golde, C., Jones, L., Bueschel, A., \& Hutchings, P. (2008). The formation of scholars: rethinking doctoral education for the twenty-first century. The Carnegie Foundation for the Advancement of Teaching.

Wao, H. O., \& Onwuegbuzie, A. J. (2011). A mixed research investigation of factors related to time to the doctorate in education. International Journal of Doctoral Studies, 6, 115-134. Retrieved from http://ijds.org/Volume6/IJDSv6p115-134Wao320.pdf

Warner, R. M. (2013). Applied statistics: From bivariate through multivariate techniques ( $\left.2^{\text {nd }} \mathrm{ed}.\right)$. Sage Publications.

Willis, B., \& Carmichael, K. D. (2011). The lived experience of late-stage doctoral student attrition in counselor education. The Qualitative Report, 16(1), 192-207.

Worthington, R. L., \& Whittaker, T. A. (2006). Scale development research: A content analysis and recommendations for best practices. The Counseling Psychologist, 34(6), 806-838. doi: $10.1177 / 0011000006288127$

Wyman, B. M. (2012). A hermeneutic phenomenological study of non-completers in online doctor of education programs [Doctoral dissertation, Liberty University]. ProQuest Dissertations and Theses. 


\section{Appendix A}

\section{Tables}

Table 1

Correlation Matrix of DDPIS Items $(\mathrm{n}=34)$

\begin{tabular}{|c|c|c|c|c|c|c|c|c|c|}
\hline & 1 & 2 & 3 & 4 & 5 & 6 & 7 & 8 & 9 \\
\hline 1 & - & $.346^{* *}$ & $.349 * *$ & $.215^{* *}$ & $.232 * *$ & $.340 * *$ & $.511^{* *}$ & $.411 * *$ & $.458 * *$ \\
\hline 2 & & - & $.464 * *$ & $.360^{* *}$ & $.317^{* *}$ & $.369^{* *}$ & $.505^{* *}$ & $.605^{* *}$ & $.476^{* *}$ \\
\hline 3 & & & - & $.384 * *$ & $.703 * *$ & $.617 * *$ & $.460 * *$ & $.468 * *$ & $.429 * *$ \\
\hline 4 & & & & - & $.471 * *$ & $.449 * *$ & $.281^{* *}$ & $.385^{* *}$ & $.387^{* *}$ \\
\hline 5 & & & & & - & $.646^{* *}$ & $.299 * *$ & $.321 * *$ & $.337 * *$ \\
\hline 6 & & & & & & - & $.459 * *$ & $.414^{* *}$ & $.388 * *$ \\
\hline 7 & & & & & & & - & $.609 * *$ & $.470 * *$ \\
\hline 8 & & & & & & & & - & $.613 * *$ \\
\hline 9 & & & & & & & & & - \\
\hline
\end{tabular}

\begin{tabular}{|c|c|c|c|c|c|c|c|c|c|c|}
\hline & 10 & 11 & 12 & 13 & 14 & 15 & 16 & 17 & 18 & 19 \\
\hline 1 & $.272 * *$ & $.371 * *$ & $.278^{* *}$ & $.332 * *$ & $.267 * *$ & $.176^{* *}$ & $.342 * *$ & $.292 * *$ & $.212 * *$ & $.226^{* *}$ \\
\hline 2 & $.633^{* *}$ & $.619 * *$ & $.582 * *$ & $.390 * *$ & $.338 * *$ & $.307 * *$ & $.414 * *$ & $.434^{* *}$ & $.323 * *$ & $.270 * *$ \\
\hline 3 & $.405^{* *}$ & $.504 * *$ & $.387 * *$ & $.604^{* *}$ & $.643 * *$ & $.620 * *$ & $.565^{* *}$ & $.194 * *$ & $.581 * *$ & $.483 * *$ \\
\hline 4 & $.462 * *$ & $.489 * *$ & $.469 * *$ & $.354 * *$ & $.375 * *$ & $.455 * *$ & $.287 * *$ & $.262 * *$ & $.428 * *$ & $.316^{* *}$ \\
\hline 5 & $.342 * *$ & $.453 * *$ & $.361 * *$ & $.574 * *$ & $.728 * *$ & $.770 * *$ & $.567 * *$ & $.157 * *$ & $.722 * *$ & $.536^{* *}$ \\
\hline 6 & $.374 * *$ & $.519 * *$ & $.403 * *$ & $.524 * *$ & $.654 * *$ & $.657 * *$ & $.538 * *$ & $.162 * *$ & $.628 * *$ & $.491 * *$ \\
\hline 7 & $.490 * *$ & $.530 * *$ & $.491 * *$ & $.426 * *$ & $.381 * *$ & $.330 * *$ & $.408 * *$ & $.390 * *$ & $.335^{* *}$ & $.357 * *$ \\
\hline 8 & $.626^{* *}$ & $.674 * *$ & $.552 * *$ & $.373 * *$ & $.366^{* *}$ & $.326 * *$ & $.415^{* *}$ & $.549 * *$ & $.326^{* *}$ & $.309 * *$ \\
\hline 9 & $.606^{* *}$ & $.598 * *$ & $.416^{* *}$ & $.418^{* *}$ & $.386^{* *}$ & $.355 * *$ & $.406 * *$ & $.449 * *$ & $.313 * *$ & $.288^{* *}$ \\
\hline 10 & - & $.696 * *$ & $.595 * *$ & $.369^{* *}$ & $.397 * *$ & $.374 * *$ & $.383 * *$ & $.440 * *$ & $.374 * *$ & $.325 * *$ \\
\hline 11 & & - & $.628^{* *}$ & $.481 * *$ & $.514 * *$ & $.469 * *$ & $.490 * *$ & $.475^{* *}$ & $.462 * *$ & $.449 * *$ \\
\hline 12 & & & - & $.459 * *$ & $.393 * *$ & $.386^{* *}$ & $.399 * *$ & $.418^{* *}$ & $.422 * *$ & $.371 * *$ \\
\hline 13 & & & & - & $.674 * *$ & $.602 * *$ & $.635^{* *}$ & $.182 * *$ & $.571 * *$ & $.578 * *$ \\
\hline 14 & & & & & - & $.814 * *$ & $.652 * *$ & $.169 * *$ & $.769 * *$ & $.666^{* *}$ \\
\hline 15 & & & & & & - & $.628 * *$ & 0.11 & $.776^{* *}$ & $.593 * *$ \\
\hline 16 & & & & & & & - & $.306^{* *}$ & $.623 * *$ & $.693 * *$ \\
\hline 17 & & & & & & & & - & $.171 * *$ & $.172 * *$ \\
\hline $\begin{array}{c}18 \\
* * \mathrm{Co} \\
* \mathrm{Cor}\end{array}$ & $\begin{array}{l}\text { on is } \\
- \text { in }\end{array}$ & corre & $\begin{array}{l}1 \text { leve } \\
\text { level } \\
\text { f } 1.0 \text {. }\end{array}$ & $\begin{array}{l}\text { (led). } \\
\text { ed). }\end{array}$ & & & & & - & $.652 * *$ \\
\hline
\end{tabular}


Table 1, continued.

Correlation Matrix of DDPIS Items $(\mathrm{n}=34)$

\begin{tabular}{|c|c|c|c|c|c|c|c|c|c|c|}
\hline & 19 & 20 & 21 & 22 & 23 & 24 & 25 & 26 & 27 & 28 \\
\hline 1 & $.226 * *$ & $.387 * *$ & $.500 * *$ & $.341 * *$ & $.344 * *$ & $.364 * *$ & $.413 * *$ & $.235 * *$ & $.503 * *$ & $.502 * *$ \\
\hline 2 & $.270 * *$ & $.621 * *$ & $.506 * *$ & $.426^{* *}$ & $.500 * *$ & $.534 * *$ & $.491 * *$ & $.373 * *$ & $.501 * *$ & $.468 * *$ \\
\hline 3 & $.483 * *$ & $.435 * *$ & $.491 * *$ & $.603 * *$ & $.394 * *$ & $.431 * *$ & $.403 * *$ & $.624 * *$ & $.405 * *$ & $.472 * *$ \\
\hline 4 & $.316^{* *}$ & $.467 * *$ & $.329 * *$ & $.342 * *$ & $.438 * *$ & $.441 * *$ & $.276^{* *}$ & $.400 * *$ & $.315^{* *}$ & $.261 * *$ \\
\hline 5 & $.536 * *$ & $.407 * *$ & $.380 * *$ & $.570 * *$ & $.282 * *$ & $.397 * *$ & $.302 * *$ & $.753 * *$ & $.331 * *$ & $.348 * *$ \\
\hline 6 & $.491 * *$ & $.406^{* *}$ & $.445^{* *}$ & $.605 * *$ & $.327 * *$ & $.434 * *$ & $.388 * *$ & $.674 * *$ & $.398 * *$ & $.425 * *$ \\
\hline 7 & $.357 * *$ & $.540 * *$ & $.555^{* *}$ & $.473 * *$ & $.442 * *$ & $.572 * *$ & $.448 * *$ & $.351 * *$ & $.519 * *$ & $.539 * *$ \\
\hline 8 & $.309 * *$ & $.594 * *$ & $.692 * *$ & $.449 * *$ & $.503 * *$ & $.601 * *$ & $.502 * *$ & $.323 * *$ & $.577 * *$ & $.586^{* *}$ \\
\hline 9 & $.288 * *$ & $.494 * *$ & $.569 * *$ & $.408 * *$ & $.567 * *$ & $.523 * *$ & $.556^{* *}$ & $.331 * *$ & $.682 * *$ & $.554 * *$ \\
\hline 10 & $.325^{* *}$ & $.687 * *$ & $.522 * *$ & $.423 * *$ & $.560 * *$ & $.592 * *$ & $.477 * *$ & $.393 * *$ & $.571 * *$ & $.488 * *$ \\
\hline 11 & $.449 * *$ & $.666^{* *}$ & $.609 * *$ & $.518^{* *}$ & $.538 * *$ & $.647 * *$ & $.537 * *$ & $.506^{* *}$ & $.550 * *$ & $.604 * *$ \\
\hline 12 & $.371 * *$ & $.614 * *$ & $.492 * *$ & $.442 * *$ & $.497 * *$ & $.624 * *$ & $.419 * *$ & $.409 * *$ & $.430 * *$ & $.473 * *$ \\
\hline 13 & $.578 * *$ & $.468^{* *}$ & $.461 * *$ & $.573 * *$ & $.322 * *$ & $.404 * *$ & $.376^{* *}$ & $.628 * *$ & $.386^{* *}$ & $.452 * *$ \\
\hline 14 & $.666^{* *}$ & $.451 * *$ & $.417^{* *}$ & $.667 * *$ & $.306^{* *}$ & $.397^{* *}$ & $.367 * *$ & $.761 * *$ & $.352 * *$ & $.396 * *$ \\
\hline 15 & $.593 * *$ & $.393 * *$ & $.400 * *$ & $.590 * *$ & $.288 * *$ & $.375^{* *}$ & $.330 * *$ & $.799 * *$ & $.328 * *$ & $.350 * *$ \\
\hline 16 & $.693 * *$ & $.543 * *$ & $.462 * *$ & $.669 * *$ & $.335^{* *}$ & $.449 * *$ & $.437 * *$ & $.627 * *$ & $.395 * *$ & $.450 * *$ \\
\hline 17 & $.172 * *$ & $.509 * *$ & $.449 * *$ & $.295 * *$ & $.427 * *$ & $.552 * *$ & $.408^{* *}$ & $.137 *$ & $.440 * *$ & $.422 * *$ \\
\hline 18 & $.652 * *$ & $.446^{* *}$ & $.378^{* *}$ & $.623 * *$ & $.320 * *$ & $.402 * *$ & $.297 * *$ & $.850 * *$ & $.340 * *$ & $.361^{* *}$ \\
\hline 19 & - & $.457 * *$ & $.315^{* *}$ & $.652 * *$ & $.307 * *$ & $.365^{* *}$ & $.297 * *$ & $.637 * *$ & $.285^{* *}$ & $.348 * *$ \\
\hline 20 & & - & $.581 * *$ & $.549 * *$ & $.508^{* *}$ & $.612^{* *}$ & $.488^{* *}$ & $.461 * *$ & $.530 * *$ & $.544 * *$ \\
\hline 21 & & & - & $.462 * *$ & $.478 * *$ & $.546^{* *}$ & $.586^{* *}$ & $.372 * *$ & $.624 * *$ & $.770 * *$ \\
\hline 22 & & & & - & $.366^{* *}$ & $.432 * *$ & $.440 * *$ & $.668 * *$ & $.444 * *$ & $.473 * *$ \\
\hline 23 & & & & & - & $.582 * *$ & $.440 * *$ & $.333 * *$ & $.605 * *$ & $.506^{* *}$ \\
\hline 24 & & & & & & - & $.469 * *$ & $.384 * *$ & $.538 * *$ & $.550 * *$ \\
\hline 25 & & & & & & & - & $.321 * *$ & $.550 * *$ & $.639 * *$ \\
\hline 26 & & & & & & & & - & $.344 * *$ & $.384 * *$ \\
\hline 27 & & & & & & & & & - & $.664 * *$ \\
\hline 28 & & & & & & & & & & - \\
\hline
\end{tabular}


Table 1, continued.

Correlation Matrix of DDPIS Items $(\mathrm{n}=34)$

\begin{tabular}{|c|c|c|c|c|c|c|}
\hline & 29 & 30 & 31 & 32 & 33 & 34 \\
\hline 1 & $.511 * *$ & $.412 * *$ & $.377 * *$ & $.278 * *$ & $.350 * *$ & $.344 * *$ \\
\hline 2 & $.466 * *$ & $.619 * *$ & $.406 * *$ & $.379 * *$ & $.642 * *$ & $.502 * *$ \\
\hline 3 & $.465 * *$ & $.485 * *$ & $.605 * *$ & $.569 * *$ & $.456 * *$ & $.408 * *$ \\
\hline 4 & $.245^{* *}$ & $.361 * *$ & $.351 * *$ & $.307 * *$ & $.511 * *$ & $.463^{* *}$ \\
\hline 5 & $.356 * *$ & $.387 * *$ & $.607 * *$ & $.544^{* *}$ & $.411^{* *}$ & $.343^{* *}$ \\
\hline 6 & $.427 * *$ & $.401 * *$ & $.629 * *$ & $.546^{* *}$ & $.463 * *$ & $.406^{* *}$ \\
\hline 7 & $.473 * *$ & $.511 * *$ & $.515^{* *}$ & $.472 * *$ & $.569 * *$ & $.533^{* *}$ \\
\hline 8 & $.510 * *$ & $.624 * *$ & $.453 * *$ & $.408^{* *}$ & $.561 * *$ & $.507^{* *}$ \\
\hline 9 & $.574 * *$ & $.601 * *$ & $.422 * *$ & $.391 * *$ & $.506^{* *}$ & $.442 * *$ \\
\hline 10 & $.451 * *$ & $.656^{* *}$ & $.462 * *$ & $.460 * *$ & $.678 * *$ & $.557 * *$ \\
\hline 11 & $.540 * *$ & $.663 * *$ & $.528 * *$ & $.517 * *$ & $.669 * *$ & $.676^{* *}$ \\
\hline 12 & $.474 * *$ & $.586^{* *}$ & $.444 * *$ & $.379 * *$ & $.720 * *$ & $.570 * *$ \\
\hline 13 & $.460 * *$ & $.469 * *$ & $.525 * *$ & $.481 * *$ & $.460 * *$ & $.390 * *$ \\
\hline 14 & $.435 * *$ & $.438 * *$ & $.639 * *$ & $.614^{* *}$ & $.444 * *$ & $.422 * *$ \\
\hline 15 & $.341^{* *}$ & $.386^{* *}$ & $.591 * *$ & $.528 * *$ & $.413^{* *}$ & $.379 * *$ \\
\hline 16 & $.429 * *$ & $.497 * *$ & $.619 * *$ & $.590 * *$ & $.502 * *$ & $.455^{* *}$ \\
\hline 17 & $.404 * *$ & $.484 * *$ & $.310^{* *}$ & $.298 * *$ & $.417 * *$ & $.444 * *$ \\
\hline 18 & $.385^{* *}$ & $.358^{* *}$ & $.645^{* *}$ & $.608^{* *}$ & $.429 * *$ & $.418^{* *}$ \\
\hline 19 & $.339 * *$ & $.375 * *$ & $.552 * *$ & $.557 * *$ & $.398 * *$ & $.418^{* *}$ \\
\hline 20 & $.491 * *$ & $.650 * *$ & $.547 * *$ & $.531^{* *}$ & $.771 * *$ & $.621^{* *}$ \\
\hline 21 & $.666^{* *}$ & $.654 * *$ & $.494 * *$ & $.390 * *$ & $.534 * *$ & $.512 * *$ \\
\hline 22 & $.492 * *$ & $.488^{* *}$ & $.714 * *$ & $.685^{* *}$ & $.500 * *$ & $.487 * *$ \\
\hline 23 & $.443 * *$ & $.551 * *$ & $.377 * *$ & $.373 * *$ & $.508 * *$ & $.520 * *$ \\
\hline 24 & $.487 * *$ & $.586^{* *}$ & $.462 * *$ & $.471 * *$ & $.638 * *$ & $.653 * *$ \\
\hline 25 & $.725^{* *}$ & $.601 * *$ & $.470 * *$ & $.463 * *$ & $.505 * *$ & $.491 * *$ \\
\hline 26 & $.394 * *$ & $.374 * *$ & $.697 * *$ & $.636^{* *}$ & $.460 * *$ & $.402 * *$ \\
\hline 27 & $.581 * *$ & $.552 * *$ & $.479 * *$ & $.426^{* *}$ & $.499 * *$ & $.453^{* *}$ \\
\hline 28 & $.765^{* *}$ & $.656^{* *}$ & $.552 * *$ & $.486^{* *}$ & $.530 * *$ & $.538^{* *}$ \\
\hline 29 & - & $.611^{* *}$ & $.525 * *$ & $.466^{* *}$ & $.479 * *$ & $.472 * *$ \\
\hline 30 & & - & $.509 * *$ & $.465^{* *}$ & $.642 * *$ & $.568^{* *}$ \\
\hline 31 & & & - & $.742 * *$ & $.522 * *$ & $.501^{* *}$ \\
\hline 32 & & & & - & $.477^{* *}$ & $.571^{* *}$ \\
\hline 33 & & & & & - & $.640 * *$ \\
\hline 34 & & & & & & - \\
\hline
\end{tabular}


Table 2

Three Factor Structure Matrix and Communalities

\begin{tabular}{|c|c|c|c|c|c|c|}
\hline \multirow[t]{2}{*}{ Item } & \multirow[t]{2}{*}{ Stem } & \multicolumn{3}{|c|}{ Factor } & \multirow[t]{2}{*}{$h_{2}$} & \multirow[t]{2}{*}{$M$} \\
\hline & & 1 & 2 & 3 & & \\
\hline 33 & $\begin{array}{l}\text { How the faculty care about you as a } \\
\text { real person. }\end{array}$ & 0.849 & & & 0.725 & 2.131 \\
\hline 20 & $\begin{array}{l}\text { How well faculty members foster } \\
\text { feelings that you personally belong in } \\
\text { this program }\end{array}$ & 0.831 & & & 0.696 & 2.234 \\
\hline 11 & $\begin{array}{l}\text { The quality of academic-related } \\
\text { contact you have with faculty } \\
\text { (consider all synchronous and } \\
\text { asynchronous interactions). }\end{array}$ & 0.821 & & & 0.698 & 2.053 \\
\hline 10 & $\begin{array}{l}\text { The enthusiasm faculty demonstrate } \\
\text { for your academic work. }\end{array}$ & 0.808 & & & 0.653 & 1.957 \\
\hline 24 & $\begin{array}{l}\text { The availability of the faculty to } \\
\text { discuss academic issues. }\end{array}$ & 0.778 & & & 0.612 & 1.883 \\
\hline 12 & $\begin{array}{l}\text { How easily you can approach faculty } \\
\text { members with your personal concerns. }\end{array}$ & 0.770 & & & 0.598 & 2.095 \\
\hline 34 & $\begin{array}{l}\text { The amount of academic-related } \\
\text { contact you have with faculty } \\
\text { (consider all synchronous and } \\
\text { asynchronous interactions). }\end{array}$ & 0.748 & & & 0.568 & 2.127 \\
\hline 8 & $\begin{array}{l}\text { The quality of academic feedback } \\
\text { provided by the faculty. }\end{array}$ & 0.747 & & & 0.609 & 1.961 \\
\hline 2 & $\begin{array}{l}\text { The encouragement faculty members } \\
\text { provide you. }\end{array}$ & 0.743 & & & 0.555 & 1.812 \\
\hline 23 & $\begin{array}{l}\text { The guidance faculty provide about } \\
\text { the dissertation process in this } \\
\text { program. }\end{array}$ & 0.662 & & & 0.455 & 2.159 \\
\hline 7 & $\begin{array}{l}\text { The quality of academic support in } \\
\text { your program (e.g., statistics } \\
\text { assistance, writing assistance, and } \\
\text { research assistance) }\end{array}$ & 0.656 & & & 0.489 & 2.322 \\
\hline 17 & $\begin{array}{l}\text { The timeliness of academic feedback } \\
\text { provided by the faculty. }\end{array}$ & 0.588 & & & 0.400 & 1.836 \\
\hline 4 & $\begin{array}{l}\text { The relationships you have developed } \\
\text { with at least one faculty member. }\end{array}$ & 0.572 & & & 0.396 & 2.170 \\
\hline 26 & $\begin{array}{l}\text { The sense of social connectedness } \\
\text { between you and your fellow students. }\end{array}$ & & -0.904 & & 0.822 & 3.159 \\
\hline
\end{tabular}


14 The level of social support you receive

$-0.880$

0.776

from fellow students.

18 The amount of social interactions you

$-0.878$

0.778

3.237 have with your fellow students.

15 The personal relationships you

$-0.873$

0.772 developed with your fellow students.

5 The quality of social interactions you

$-0.829$

0.692 have with your fellow students.

31 The opportunities you have to learn

$-0.764$

0.646

2.751 from your fellow students.

22 The amount of constructive feedback

$-0.761$

0.618 you receive from your fellow students.

6 How using various distance methods

$-0.752$

0.579

2.688 to communicate (e.g., telephone, live video, online chat, email, and/or social media sites) has helped you feel personally connected with other students.

16 The level of cooperation with your $-0.742$

0.578

2.354 fellow students when completing program requirements.

3 The quality of academic-related $-0.734$ interactions you have with other students.

19 The willingness of students to provide $-0.728$

0.532

2.507 academic -related help to other students.

13 The level of mutual trust among the students in this program.

32 The frequency of academic-related $-0.712$ interactions you have with other students.

28 The quality of the curriculum in your program.

29 The relevancy of the curriculum to your goals.

21 The quality of instruction in your program.

25 How you are finding the coursework in your program to be a good fit for you (e.g., there is good alignment with personal interests, application to future

$\begin{array}{lll}-0.871 & 0.787 & 1.812 \\ -0.823 & 0.713 & 1.861 \\ -0.791 & 0.689 & 1.794 \\ -0.723 & 0.563 & 1.844\end{array}$


job goals, application to real life, or other similar reasons).

27 How the coursework prepares students

$-0.704 \quad 0.569 \quad 2.159$

for the dissertation process.

1 The sequencing of the coursework in $\quad \begin{array}{llll}-0.600 & 0.369 & 1.847\end{array}$ your program.

\section{Removed}

9 How the dissertation process is

preparing you, or will prepare you, for your goals.

30 Your level of trust in the faculty.

Note. 1 = Faculty Integration, 2 = Student Integration, 3 = Curriculum Integration, $h_{2}=$ communalities. Sorted by size and only the highest loadings for each factor retained for ease in viewing. 